\title{
Orange Banana Flavor
}

National Cancer Institute

\section{Source}

National Cancer Institute. Orange Banana Flavor. NCI Thesaurus. Code C73405.

A characteristic of a medicinal product, specifying that its most predominant agreeable savor detected by the unified sensation of taste and olfactory receptors resembles orange and banana combination. 